\title{
KNOWLEDGE OF STROKE AMONG A BRAZILIAN URBAN POPULATION
}

\author{
Raimundo Nonato Campos-Sousa', Vítor Yamashiro Rocha Soares², \\ Kelson James Silva Almeida², Lorena Ibiapina Mendes de Carvalho², \\ Kelson Sousa Jacobina ${ }^{2}$, Arnaldo Escórcio Athayde Netto², \\ Eduardo de Almeida Macêdó, Lorenna Andrade Veloso
}

\begin{abstract}
Knowledge of the population in regards to stroke has clinical and epidemiological importance. Prompt identification of the symptoms means efficient medical attendance within the window of therapeutic opportunities reducing significantly the morbi-mortality. Our aim was to evaluate the level of knowledge of the population of Teresina (PI) concerning factors of risk, symptoms and treatment of stroke. The door-to-door study was carried out by means of a standardized application of questionnaire on risk factors, symptoms and attitude when faced with a stroke victim. 991 forms were selected. Factors of risk more cited were hypertension identified by 416 [42.0\%] and hyperlipidemia 284 [28.7\%]. The most remembered symptoms were headache 277 [28.0\%] and hemiplegia 219 [22.1\%]. $375(37.8 \%)$ respondents were unable to identify any risk factors and and $410(41.4 \%)$ any symptom. The lack of knowledge of the population of Teresina in relation to stroke reflects the need for intervention through public and professional educational campaigns.
\end{abstract}

KEY WORDS: population knowledge, stroke, factors of risk.

\section{Conhecimento sobre doenças cerebrovasculares em uma população urbana no Brasil}

RESUMO - O conhecimento da população sobre doenças cerebrovasculares (DCV) possui importância clínica e epidemiológica. A rápida identificação dos sintomas significará atendimento médico eficiente dentro das janelas de oportunidades terapêuticas reduzindo significativamente a morbimortalidade. Objetivou-se avaliar o nível de conhecimento da população de Teresina (PI) acerca dos fatores de risco, sintomas e tratamento das DCV. O estudo populacional, porta-a-porta, foi conduzido mediante aplicação padronizada de um questionário sobre fatores de risco, sintomas e atitude diante de um caso de DCV. Foram eleitos 991 formulários preenchidos. Os fatores de risco mais citados foram hipertensão arterial identificada por 416 [42,0\%] e hiperlipidemia 284 [28,7\%]. Os sintomas mais lembrados foram cefaléia 277 [28,0\%] e hemiplegia 219 [22,1\%]. Não identificaram nenhum fator de risco $375(37,8 \%)$ respondedores e $410(41,4 \%)$, nenhum sintoma. O reduzido conhecimento da população de Teresina com relação às DCV reflete a necessidade de intervenção com campanhas educativas públicas e profissionais nesta população.

PALAVRAS-CHAVE: conhecimento populacional, doenças cerebrovasculares, fatores de risco.

Currently, stroke represents a serious problem in public health ${ }^{1,2}$. Contributing to this is the aging of the population, lack of knowledge in regards to cerebrovascular disease (CVD) and increased frequency of the risk factors, mainly, hypertension ${ }^{3-6}$. The main clinical manifestations are: paralysis, dysarthria, aphasia, vision alterations, headache, numbness, dizziness or weakness ${ }^{4-6}$. The public's knowledge of these warning signs is of extreme importance. Quick identification of these signs means a more efficient medical attendance within the windows of therapeutic oppor- tunities. Rapid reperfusion with thrombolytic therapy within 3 hours of the onset of symptoms is beneficial and reduces morbidity-mortality ${ }^{2,7-9}$.

The public's level of knowledge of the symptoms and risk factors for stroke, as well as the prevalence of risk factors has little been studied in Brazil, especially in the Northeast. Thus, it is of great clinical and epidemiological interest to know the magnitude of the problem, so that strategies can be adopted to minimize the unfavorable effects of stroke.

The objective of this study is to evaluate the lev-

Disciplina de Neurologia do Departamento de Medicina Especializada e Clínica Neurológica do Hospital Getúlio Vargas da Universidade Federal do Piauí, Teresina PI, Brasil (UFPI): ${ }^{1}$ Neurologista e Professor Titular da Disciplina de Neurologia da UFPI; ${ }^{2}$ Acadêmico de Medicina da UFPI. 
el of knowledge of the population of Teresina, PI with 40 years of age or more in relation to the signs, symptoms and risk factors of the cerebrovascular illnesses, along with the treatment when someone is having an acute stroke.

\section{METHOD}

Place of study - The study was carried out in Teresina, Piauí, city located in the Brazilian northeast - from January to December of 2005. Within the population of 715,360 people, 76,603 are between the ages of 40 and 49 years; 43,104 are between 50 and 59 years of age; 25,142 are between 60 and 69 years and 19,294 are 70 years or older ${ }^{10}$.

In Teresina, health services are structured in accordance to recommendations by the Health Department, which attends the low income population with teams from the Family Health Program (PSF) together with assistance in City hospitals located in different parts of the city. Patients who require attendance in hospitals of high complexity are directed to a public hospital of reference (Hospital Getulio Vargas) or the ample network of private hospitals. There are also ambulances and teams that give pre-hospital care and directs the injured patient to a hospital where appropriate treatment can be given ${ }^{11}$.

Population survey - The survey is a transversal, community, door-to-door study, carried out through the application of a standardized questionnaire composed of five sections. The first section was in regards to age, sex, race, education and family income. The second section inquired about the knowledge of risk factors for stroke. Initially an open question was asked (spontaneous answer) and then a closed question was asked about the following risk factors: hypertension, smoking, cardiopathy (heart problems), hyperlipidemia (elevated cholesterol), diabetes (blood sugar), obesity (overweight), stress (nervousness), alcoholism and oral contraceptives.

In the third section, the knowledge of warning signs and symptoms of stroke were surveyed initially with a spontaneous form (open questions) and later with a closed question (closed answer) about the signs and symptoms: hemiparesis (weakness), hemiesthesis (numbness or tingling), hemiplegia (paralysis), visual alterations, dysarthria (slurred speech), headache, diplopia (double vision) and aphasia (difficulty or inability to speak).

The fourth section evaluated the knowledge of the presence of risk factors in the interviewees, such as: hypertension, diabetes, hereditary and personal antecedents of stroke, cardiopathies, arrhythmias, hyperlipidemia, use of tobacco and alcoholism. In the last section, the interviewee was questioned about the correct behavior when placed in the situation of someone having an acute stroke in regards to the treatment options and health services. All the possible health services existing in the city were given as suggested alternatives. The transport of the patient to a reference hospital with support for the appropriate attendance inside the therapeutical window was adopted as the correct attitude when dealing with a stroke victim.
The random population sample was calculated with amostral error of $2 \%$, with a reliability level of $95 \%{ }^{12}$. A total of 1,026 residences, distributed in the 74 parts of the city, were involved in the study, being that in each home only one person 40 years or older was interviewed.

Statistical analysis - The results were analyzed with the statistical program SPSS 11.0 for Windows. Test " $t$ " of student for average comparison was applied and test $\chi^{2}$ (quisquare) was used in the evaluation of the ratios and nominal variables. The dependent variables - " knowledge of two or more factor of risk", "knowledge of two or more symptoms" and "correct attitude when dealing with an acute stroke victim" - were evaluated separately in previous univaried models. The other questioned variables were independent variables in each of these analyses. Those that presented statistical correlation with each of the three dependent variables in the study were included as co-variables in multivariate analyses using logistic regression. Lost data was excluded from the analysis. The value of $p \leq 0.05$ as statistically significant was adopted ${ }^{13}$.

The Committee of Ethics in Research of the Federal University of Piaui (UFPI) approved the present study.

\section{RESULTS}

A total of 1,026 people, 40 years or older, were interviewed. However, 991 filled-out forms were chosen. The others were excluded because of errors when filling out the forms. The demographic characteristics of the participants are in Table 1. When asked if they knew some of the risk factors for stroke, $375(37.8 \%)$ answered that they had no knowledge and $616(62.2 \%)$ knew at least one factor of risk. Just, $417(42.1 \%)$ of the interviewed knew two or more risk factors. In a univariate analysis, individuals were between 40 and 55 years of age $(p<0.001)$, female sex $(p=0.016)$, up to 12 years of education $(p<0.001)$, family income more than 1,300 reals per month $(p<0.001)$, hyperlipidemia history $(p=0.011)$, familial antecedents of stroke $(p=0.012)$ were associated to having more knowledge concerning the factors of risk. Hypertension was the most cited factor by the population of the city of Teresina (Table 2).

In regards to the signs and symptoms of stroke, $410(41.4 \%)$ answered that they did not have any knowledge and 581 (58.6\%) knew at least one sign or symptom. Only $324(32.7 \%)$ of the respondents knew two or more symptoms of stroke. The female sex $(p<0.001)$, higher family income $(p=0.033)$, personal $(p=0.019)$ and familial $(p=0.010)$ antecedent history had greater knowledge of the symptoms of stroke in a univariate comparison. The symptom most cited by the population of Teresina was headache, remembered spontaneously by $277(28 \%)$ interviewed (Table 3). 
Table 1. Demographic characteristics of the respondents.

\begin{tabular}{lc}
\hline Age, mean \pm SD years & $56.7 \pm 11.9(40-97)$ \\
Sex, $\mathrm{n}(\%)$ & $305(31.0)$ \\
$\quad$ Male & $686(69.0)$ \\
Female & \\
Race, $\mathrm{n}(\%)$ & $257(26.0)$ \\
$\quad$ Write & $179(18.1)$ \\
Niger & $551(55.8)$ \\
Medium Brown & \\
Education, $\mathrm{n}(\%)$ & $202(20.4)$ \\
None & $480(48.5)$ \\
Primary & $242(24.5)$ \\
Secundary & $65(6.6)$ \\
Tertiary & \\
Income, $\mathrm{n}(\%)$ & $73(7.4)$ \\
$<\mathrm{R} \$ 260.00$ & $575(58.1)$ \\
$\mathrm{R} \$ 260$ to $\mathrm{R} \$ 780.00$ & $179(18.1)$ \\
$\mathrm{R} \$ 780.00$ to $\mathrm{R} \$ 1,300.00$ & $163(16.5)$ \\
$>\mathrm{R} \$ 1,300$ &
\end{tabular}

With relation to the risk factors to which the respondents would be exposed, hypertension was most frequent. Around $40 \%$ said they were hypertensive. Familial cases of stroke were related by $28 \%$ of the participants, while $5.1 \%$ had already had a stroke. Seventeen percent smoked and $36 \%$ had stopped smoking and $28 \%$ of the interviewees drank alcoholic beverages frequently. Just, $8 \%$ of those questioned were diabetic.

In relation to the reaction of the population when faced with an acute stroke victim, 9 (0.9\%) answered that it was not an emergency, 54 (5.4\%) did not know and 928 (93.6\%) answered that the victim needed immediate treatment. Of those who considered stroke an emergency, 765 (82.4\%) of the participants would take the person to the hospital quickly, and 401 (52.4\%) would take the person to the hospitals in their section of the city (Table 4). With regards to the transportation used for assisting the victim, $26.1 \%$ would use their own car; $36.8 \%$, the Services of Mobile Emergency Attendance (SAMU); $22.4 \%$ would call a taxi; $13.9 \%$, other means and $0.8 \%$ had no answer. About 36.5\% (362) of those interviewed would follow the correct procedure in an emergency situation for an acute stroke victim. With the univariate analysis, more education $(p<0.001)$, higher income $(p<0.001)$ and the awareness of two or more factors of risk $(p<0,001)$ were predictive for correct response to a stroke victim.

In a logistic regression analysis, individuals between the ages of 40 and 55 years, with a higher level of education (above 12 years of schooling), a good
Table 2. Knowledge of the respondents of stroke factors of risk.

\begin{tabular}{lcc}
\hline Factors of risk & \multicolumn{2}{c}{ Factors of risk } \\
\cline { 2 - 3 } & $\begin{array}{c}\text { Evoked } \\
\text { spontaneously }\end{array}$ & $\begin{array}{c}\text { Remembered } \\
\text { when enumerated }\end{array}$ \\
\hline Hypertension & $416(42.0 \%)$ & $915(92.4 \%)$ \\
Hyperlipidemia & $284(28.7 \%)$ & $853(86.2 \%)$ \\
Stress & $145(14.6 \%)$ & $836(84.4 \%)$ \\
Smoking & $110(11.1 \%)$ & $829(83.7 \%)$ \\
Alcohol & $97(9.8 \%)$ & $818(82.6 \%)$ \\
Diabetes & $57(5.8 \%)$ & $631(63.7 \%)$ \\
Obesity & $51(5.1 \%)$ & $824(83.2 \%)$ \\
Cardiopathy & $44(4.4 \%)$ & $764(77.2 \%)$ \\
Oral contraceptive & $1(0.1 \%)$ & $165(18.0 \%)$ \\
\hline
\end{tabular}

Table 3. Knowledge of the respondents of stroke warning sings.

\begin{tabular}{lcc}
\hline Sings and symptoms & \multicolumn{2}{c}{ Sings and symptoms } \\
\cline { 2 - 3 } & $\begin{array}{c}\text { Evoked } \\
\text { spontaneously }\end{array}$ & $\begin{array}{c}\text { Remembered } \\
\text { when enumerated }\end{array}$ \\
\hline Headache & $277(28.0 \%)$ & $852(86.0 \%)$ \\
Hemiplegia & $219(22.1 \%)$ & $874(88.2 \%)$ \\
Hemiesthesis & $179(18.1 \%)$ & $852(86.0 \%)$ \\
Aphasia & $72(7.3 \%)$ & $818(82.5 \%)$ \\
Hemiparesis & $65(6.6 \%)$ & $730(73.3 \%)$ \\
Trouble speaking & $52(5.2 \%)$ & $842(85.0 \%)$ \\
Visual alterations & $36(3.6 \%)$ & $658(66.4 \%)$ \\
Double vision & $3(0.3 \%)$ & $551(55.6 \%)$ \\
\hline
\end{tabular}

Table 4. Respondents' reactions in a case of acute stroke.

\begin{tabular}{lc}
\hline Reactions & Frequency n (\%) \\
\hline Hospital & $765(82.4)$ \\
Hospital Getúlio Vargas* & $190(24.8)$ \\
Private hospital & $164(21.4)$ \\
Hospital of quarter & $401(52.4)$ \\
Others & $7(0.9)$ \\
Don't know & $3(0.4)$ \\
Remedy caretaker & $116(12.5)$ \\
Private doctor's office & $28(3.0)$ \\
It would wait & $9(1.0)$ \\
Others & $10(1.0)$ \\
\hline
\end{tabular}

*Public Hospital of Regional Reference with Urgency Service.

income and a hyperlipidemia history were more inclined to identify two or more risk factors when compared with the respondents without these characteristics. Only the women, with a higher income and with personal antecedents of stroke were associated with more knowledge about symptoms of stroke. 
More education and a higher income were predictive to correct reaction in the case of acute stroke.

\section{DISCUSSION}

Identification of the main factors of risk for cerebrovascular disease (CVD) and the clinical presentation have direct implication in the prevention and rapid intervention of stroke patient within possible therapeutic measures. The present research showed little knowledge in relation to stroke by the urban population of the city of Teresina (PI) when compared to other surveys published. Low family income and reduced level of education of the interviewees are the detected causes. Besides this, a random doorto-door study was conducted. Previous stroke surveys were carried out by phone or in the hospital after the event ${ }^{14-17}$. In this study it was possible to have selected sampling with common interest to the happening while in the other studies individuals without telephone service, many of low financial income were usually excluded.

Approximately, $38 \%$ and $42 \%$ of the interviewed responded that they had no knowledge of any of the risk factors and knew of no symptoms of stroke, respectively. In the State of Paraná, a study lead by Novak et al. ${ }^{17}$, showed that $1.8 \%$ of the participants did not recognize one risk factor and only $2.7 \%$ could not recognize any symptoms. This result reflects, in part, the level of education of the population of Paraná, where $97 \%$ of the participants had 12 years or more of education. Mainly young people made up the study group. Seventy three percent of the participants were between 16 and 35 years of age who had more access to information on health and illnesses from different forms. Hypertension also was the risk factor which people remembered more frequently, while lost of consciousness and headache were the symptoms most frequently cited.

In 1995, a study was carried out in Ohio, in the United States, through interviews over the phone. Pancioli et al. ${ }^{14}$ showed that $57 \%$ of the interviewed had knowledge of at least one sign of stroke, while dizziness was the symptom most indicated (24\%). Sixty eight percent listed correctly at least one risk factor among which hypertension and stress were the most cited. In 2000, Schneider et al. ${ }^{15}$, in a study also conducted in Ohio, showed that $70 \%$ of the individuals had correctly identified at least one symptom and $72 \%$, at least one risk factor. Five years after the study of Pancioli et al. ${ }^{14}$ the only significant evolution was knowledge of the symptoms. A possible explanation for this improvement might be the approval of tissue activator plasminogen (TPA) by the FDA (Food and Drug Administration) for acute treatment of stroke and the information on symptoms divulgated in the media. Morgan et al. ${ }^{18}$ found that $96 \%$ of the studied population considered the immediate treatment of stroke extremely important. In the present study, similar results were reached $(93.6 \%$ considered immediate treatment a necessity), with increasing percentages in the higher education levels. In our sampling, $82.4 \%$ of the interviewed would go to the hospital quickly, which would make it possible to give early therapeutic treatment within the so-called "therapeutic window" for stroke.

A reduced knowledge of cerebrovascular illnesses by the population target reflects the real necessity of intervention with informative and enlightening campaigns, since stroke is of the main cause of death in the city ${ }^{19}$. The vehicles of information on stroke most cited by the participants in some studies are television, magazines and newspapers, family and friends, followed by health professionals and educational campaigns ${ }^{15,16}$. Stern et al. ${ }^{20}$, analyzed the effect of educational programs on stroke applied in the community of Minnesota, and noticed an increase in the population's knowledge of risk factors, symptoms and action that should be taken when witnessing an acute stroke, independent of race or educational level. Other studies also point to a greater awareness after informative campaigns ${ }^{21,22}$. On the other hand, studies show a positive effect over long periods is necessary. An increase of institutional campaigns, lectures and simulation must occur, especially in schools, thus divulging the most frequent risk factors and symptoms.

The knowledge of the main factors of risk and symptoms of cerebrovascular illnesses would have direct implications on the ratio of mortality of these pathologies. While in 2004, stroke was the main cause of death in Brazil ${ }^{19}$, a decline in mortality in developed countries was observed. Liu et al..$^{23} \mathrm{em}$ phasizes the interference in two modifiable factors of risk: hypertension and smoking. In Japan, a rigid control of the arterial pressure and a reduction in the habit of smoking caused a significant decline in the stroke mortality rate from the 90 's. A similar phenomenon was also seen in the United States ${ }^{24}$.

In conclusion, the present study showed the little knowledge the population of Teresina has in relation to the identification of the risk factors and symptoms of CVD. Corroborating with the other studies, younger individuals, of the feminine sex and with more education and family income were seen to have 
more knowledge concerning cerebrovascular illnesses $^{14,16,25-27}$. This reflects the necessity of intervention with public and professional educational campaigns in the community. Alberts et al. ${ }^{21}$ proved the possibility of decreasing the time of arrival in the hospital of stroke victims through campaigns that focused on the recognition of symptoms and the necessity of rapid treatment. The knowledge of stroke risk factors and symptoms has epidemiologist and clinical relevance. The correct identification of the risk factors would cause a reduction of the incidence and morbimortality. Quick recognition of the symptoms would make adequate treatment possible and would minimize the unfavorable effects of stroke.

\section{REFERENCES}

1. Smith WS, Hauser SL, Easton JD. Doenças Cerebrovasculares. In Braunwald E, Fauci AS, Kasper DL, Hauser SL, Longo DL, Jameson JL (Eds). Harrison: Medicina Interna. (15.Ed). Rio de Janeiro: McGraw-Hill, 2002.

2. Davis S, Lees K, Donnan G. Treating the acute stroke patient as an emergency: current practices and future opportunities. J Clin Pract 2006;60: 399-407.

3. Pires SL, Gagliardi RJ, Garzoni ML. Estudo das freqüências dos principais fatores de risco para acidente vascular cerebral isquêmico em idosos. Arq Neuropsiquiatr 2004;62:844-851.

4. Bronner LL, Kanter DS, Manson JE. Primary prevention of stroke. N Engl J Med 1995;333:1392-1400.

5. Inzitari D, Eliasziw M, Gates P, Sharpe BL, Chan RKT. The causes and risk of stroke in patients with asymptomatic internal-carotid-artery stenosis. N Engl J Med 2000;342:1693-1700.

6. Lessa I. Epidemiologia das doenças cerebrovasculares no Brasil. Rev Soc Cardiol São Paulo 1999;4:509-518.

7. Zetola VHF, Novak EM, Camargo CHF, et al. Acidente vascular cerebral em pacientes jovens: análise de 164 casos. Arq Neuropsiquiatr 2001;59: 740-745.

8. Neto JE, Lotufo PA, Lólio CA. Tratamento da hipertensão e declínio da mortalidade por acidentes vasculares cerebrais. Rev Saude Publ 1990; 24:332-336.

9. Bushnell CD, Goldstain LB. Physician knowledge and practices in the evaluation of coagulopathies in stroke patients. Stroke 2002;33:948-953.
10. IBGE - Instituto Brasileiro de Geografia e Estatística. MPO - Ministério do Planejamento e Orçamento. Contagem da população - 2000.

11. Secretaria Estadual de Saúde do Piauí - SESAPI. Municipalização da Saúde - Documentos Legais. Sistema Único de Saúde - SUS. 1996.

12. Nunes da Silva NN. Amostragem probabilística. São Paulo: Editora Edusp, 1998.

13. Triola MF. Introdução à Estatística. 7.Ed. Rio de Janeiro: Editora LTC, 1999:158-168.

14. Pancioli AM, Broderick J, Kothari R, et al. Public perception of stroke warning signs and knowledge of potential risk factors. JAMA 1998; 279:1288-1292.

15. Schneider AT, Pancioli AM, Khoury JC, et al. Trends in community knowledge of the warning signs and risk factors for stroke. JAMA 2003; 289:343-346.

16. Yoon SS, Heller RF, Levi C, Wiggers J, Fitzgerald PE. Knowledge of stroke risk factors, warning symptoms, and treatment among an Australian urban population. Stroke 2001;32:1926-1930.

17. Nóvak EM, Zétola VHF, Muzzio JA, Puppi M, Carraro H Jr, Werneck LC. Conhecimento leigo sobre doença vascular encefálica. Arq Neuropsiquiatr 2003;61:772-776.

18. Morgan LJ, Chambers R, Banerji J, Gater J, Jordan J. Consumers leading public consultation: the general public's knowledge of stroke. Fam Pract 2005;22:8-14.

19. Ministério da Saúde. DATASUS, www.datasus.gov.br. Acesso em 20 de julho de 2006.

20. Stern EB, Berman M, Thomas JJ, Klassen AC. Community education for stroke awareness: an efficacy study. Stroke 1999;30:720-723.

21. Alberts MJ, Perry A, Dawson DV, Bertels C. Effects of public and professional education on reducing the delay in presentation and referral of stroke patients. Stroke 1992;23:352-356.

22. Silver FL, Rubini F, Black D, Hodgson CS. Advertising strategies to increase public knowledge of the warning signs of stroke. Stroke 2003; 34:1965-1969.

23. Liu L, Ikeda K, Yamori Y. Changes in stroke mortality rates for 1950 to 1997: a great slowdown of decline trend in Japan. Stroke 2001;32:17451749.

24. Cooper R, Sempos C, Hsich SC, Kovar MG. Slowdown in the decline of stroke mortality in the United States, 1978-1986. Stroke 1990;21:12741279 .

25. Reeves MJ, Hogan JG, Rafferty AP. Knowledge of stroke risk factors and warning signs among Michigan adults. Neurology 2002;59:1547-1552.

26. Blades LL, Oser CS, Dietrich DW, et al. Rural community knowledge of stroke warning signs and risk factors. Preventing Chronic Disease 2005;2:1-8.

27. Pandian JD, Jaison A, Deepak SS, et al. Public awareness of warning symptoms, risk factors, and treatment of stroke in Northwest India. Stroke 2005;36:644-648. 